\title{
UMA ENTREVISTA COM O PROF. NOGUCHI
}

Com alvoroçado coração, tomámos aquella manhã de domingo a direcção do Hotel Esplanada.

Iamos fallar com Noguchi!

Iamos fallar com um representante dessa nova geração de santos, que devotam ao aperfeiçoamento humano toda uma vida de trabalhos e de sacrificios!

Iamos fallar com um membro dessa pleiade de heroes, que por muito alto coliocarem seu Ideal, desconhecem essa face da vida que se chama prazer!

Santo Agostinho, Shakespeare, Noguchi - o santo, o artista, o sabio. Qual delles terá feito mais pela humanidade?

Dizer do valor de Noguchi é tarefa ociosa e esforço desperdiçado. A importancia de seus trabalhos é do conhecimento de cada um, e enumeral-os é desfiar um rosario de triumphos maravilhosos, cada um dos quaes sufficiente para redimir a inutilidade da vida de individuos, dos quaes nosso meio social conta numerosos e soberbos exemplares, que, numa adoravel ingenuidade, confundem altruismo com estomago, e trabalho com cavallos de corrida.

Mas ha um facto que tem, na demonstração do merito de Noguchi, o valor de argumento crucial. E' a posição que esse sabio occupa nos Estados Unidos. Sabidos os sentimentos com que se olham esses dois póvos - o japonez e o norte-americano - é facil comprehender o incommensuravel valor de um japonez para que norte-americanos o chamassem ao seu seio e o prestigiassem como o prestigiam.

- Qual é, em sua opinião, a caracteristica dominante da classe medica brasileira? - foi o que primeiro perguntámos ao Prof. Noguchi, logo que elle se poz á nossa disposição, no salão nobre do Hotel. 
- A independencia, respondeu o Prof. Noguchi sem hesitar. Em todos os medicos brasileiros com quem trabalhei, observei a maior reserva em emittir os seus juizos. Nunca affirmavam sem antes ter observado, experimentado, estudado; nunca acceitaram uma opinião minha, que não a controlassem antes, rigorosamente, por todos os meios de que dispunham. Este será sempre o motivo principal do muito que respeito os medicos brasileiros.

- Acha o Prof. Noguchi o actual Serviço de Prophylaxia do Brasil bastante efficiente, não em sua quantidade mas em sua qualidade, para o combate aos males a que se propõe combater?

- Não ha duvida. O serviço organisado e dirigido por Chagas, alliado á Rockfeller, ha de dominar (overcamp) as epidemias. Chagas é um scientista de extraordinario valor.

- Qual será, Prof. Noguchi, a causa principal deste desamor com que as sciencias de laboratorio são tidas pelos estudantes?

- Não conheço sufficientemente o povo brasileiro para poder responder. Creio que será pela falta de medicos em relação á população, e por isso os medicos precisam ir logo para a pratica. Ha uma interdependencia entre a clinica e o laboratorio: a clinica fornece os problemas que o laboratorio ha de resolver; deste modo, o laboratorio, apenas recebendo os problemas, tem um aspecto de inferioridade e subordinação que apparentemente o desvalorisa. Mas o laboratorio, alem de grandes recursos materiaes, exige um temperamento especial, que possuiam todos os medicos brasileiros que commigo trabalharam.

$\therefore$ - Que informações poderia o sr. nos dar sobre as organisações academicas no Japão? Este parece-nos um problema capital para a vida dos estudantes.

- Meu amigo, não the posso responder como desejaria. Ha 20 annos que não vivo no Japão, e nada conheço do que me pergunta.

- Mas qual é sua opinião pessoal sobre a importancia das asssociações academicas?

- Ainda aqui não the dou uma resposta satisfactoria, pois tenho pássado minha vida fechado dentro de um laboratorio. Estou alheio ás condições da vida academica. O sr. deve conversar com o sr. Miller, da Rockfeller, que veiu commigo, e que conhece perfeitamente as organisações dos moços nos Estados Unidos.

- Prof. Noguchi, qual o conselho que sua experiencia dita aos estudantes de São Paulo?

- Ser original. Não se deixar influenciar é o que basta para avançar muito. Conheci Chagas, Neiva, Pirajá. Aragão, Lutz, entre outros. São grandes homens no trabalho (big people in the work). Os mesmos deve haver na Clinica. São extraordinarios 
pelo seu espirito de independencia. Conheci tambem João Flores e Valladares, na Bahia. Tive a sorte de interessal-os em meus trabalhos, e de ter trabalhado com elles. Só acceitavam as conclusões de seus trabalhos pessoaes, nunca acceitando sem discussão o que eu thes dizia. Vou daqui de S. Paulo muito satisfeito. Tenho a maior esperança no futuro da sciencia medica do Brasil e de São Paulo. Dr. Paula Souza, Dr. Borges, Dr. Lambert e muitos outros, estudam muito por si proprios. Agradeço aos estudantes mandarem o Guimarães me receber.

Davamos por finda a entrevista.

- Prof. Noguchi, temos ainda um pedido a fazer á sua gentileza. Os estudantes de Medicina de São Paulo querem um seu retrato para pôr na sala de honra de sua sociedade, ao lado do retrato de Oswaldo Cruz.

- Oh não! Eu não estou tão alto como Oswaldo Cruz. Espero estar algum dia. Meu retrato fica bem em qualquer logar. Mas não tenho retratos aqui. Estão todos no Rio. Eu mandarei para o Instituto de Hygiene, ao Dr. Borges.

Já na escada, como the pedissemos desculpas pelo máo inglez em que o entrevistáramos, elle nos interrompeu:

- Não. Está muto bom. Saiba aproveital-o. Uma viagem de u:m ou dois annos aos Estados Unidos aproveita muito a quem a fizer.

Os dois minutos que the pediramos iam já em quinze. Despedimonos, apresentando ainda uma vez ao sabio japonez as expressões da devotada admiração dos estudantes paulistas.

\section{ASSIGNEM A "REVISTA DE MEDICINA"}

BRASIL (6 numeros)

$10 \$ 000$

ESTRANGEIRO

$18 \$ 000$

NUMERO AVULSO

$2 \$ 500$ 